\title{
Improving Grammar Achievement through Using Metatalk considering Iranian EFL Learners with Advanced Language Proficiency
}

\author{
Farnaz Sahebkheir \\ Assistant Professor of TEFL, Department of English Language Teaching, Tabriz Branch, Islamic Azad University, \\ Tabriz, Iran
}

\section{*Corresponding Author}

Farnaz Sahebkheir

\section{Article History}

Received: 26.06 .2020

Accepted: 03.07.2020

Published: 08.07.2020

\begin{abstract}
The aim of the present study is to investigate the effect of metatalk activity on Iranian Advanced EFL Learners' knowledge of passive tenses. 60 advanced level institute learners, who participated in this study, were randomly selected via a language proficiency test (TOEFL). Those who got \pm 1 SD in the test were chosen. They were randomly assigned into two experimental and control groups with 20 participants in every group. An English grammar test related to the usage of passive tenses was administered to both groups in the pre and post-tests. Treatment sessions lasted for 8 sessions but with different methodologies. Teacher in both groups explained about different passive tenses in every treatment sessions. However, learners in the experimental group were treated with metatalk activity and they tried to complete exercises collaboratively with their peers and teachers. They have to complete a dictogloss task with the help of their peers due to focus on learning passive verb tenses. While the control group did not received dictogloss as a metatalk activity and completed the exercises at home and the next session checked the answers. A posttest of grammar was then administered to both groups. The data of the study were analyzed using the independent samples t-test to compare the means of grammar knowledge in both groups. The results revealed that Iranian EFL learners in the experimental group received higher score in the grammar test after being treated with metatalk activity for 8 sessions. It can be conclude that metatalk is an effective method for teaching grammatical knowledge and teachers can use it in their classes.
\end{abstract}

Keywords: EFL learners, Grammar Learning, Metatalk, Passive Tense.

\section{INTRODUCTION}

Swain's [1] defines metatalk as "the metalinguistic function of her output hypothesis: a learner uses language to indicate an awareness of something about their own, or their interlocutor's use of language". Similarly, Vanderheijden [2] mentions that an example of metatalk could be asking the partner a simple question like, - Shouldn't that word have $\mathrm{X}$ ending? Swain did not mention of L1 or L2 use in metatalk; it means that the language of expression is also irrelevant. Another assumption made by Swain is that metatalk is a cognitive tool. She characterizes metatalk as problem-solving language process. Accordingly, it not only helps learners in language learning, but also serves researchers in cognitive processes. Metatalk in this way is related to sociocultural learning.

Initially, Swain [3] introduced the term metatalk (MT) in relation to the Comprehensible Output Hypothesis. She mentioned the Krashen's [4] Input Hypothesis and concluded that input is not sufficient for achieving native-like proficiency in the L2. She focused on output. Swain mentioned three functions of output in L2 learning: noticing, hypothesis-testing, and metalinguistic reflection (or metatalk). She concluded that in output production, L2 learners may notice the gaps between what they want to say and what they can actually say, they may experiment with the language and test their own hypotheses, and may engage in metalinguistic reflections on their use and knowledge of the target language [5].

Copyright @ 2020: This is an open-access article distributed under the terms of the Creative Commons Attribution license which permits unrestricted use, distribution, and reproduction in any medium for non commercial use (NonCommercial, or CC-BY-NC) provided the original author and source are credited. 
Furthermore, Kuiken and Vedder [6] discussed about metacognition and its facilitative effect on L2 acquisition as it helps learners understand relations between meaning, form, and function. In addition, metacognition is facilitated by interaction. Language production has been described as enabling learners to deepen their awareness of grammatical and lexical matters, test hypotheses with others, receive feedback and reprocess their output. In this manner, learners engage in co-constructing their L2. Moreover, Ellis [7] discussed the nature of tasks and interaction in connection with metacognition. She addressed production tasks in which learners are prompted in problem solving tasks. It is in these settings that metacognitive verbalization arises as learners are engaged in meaningful interactions. Such verbalizations may lead learners to understand the relationship between meaning, form, and function. At the same time, these verbalizations allow researchers to observe learners working with hypotheses as they experience the language learning process. Like other forms of speech, MT can serve individuals first and foremost by mediating knowledge as they negotiate with an interlocutor. Even if language is used for mediation in a social context, individuals take advantage of it differently and will organize their own thoughts in a unique manner, as compared to their peers in the same social task.

This study aims to investigate the effects of using Metatalk Activity on Iranian advanced EFL learners' knowledge of tense. The main question for this study is as follows.

1. Does students' knowledge of passive tense change according to the using of metatalk?

\section{METHOD Participants}

The sample of this study included 40 learners studying EFL at the advanced level in a language institute. They were selected based on a modified TOEFL test. The participants whose scores were at least one standard deviation below or above the mean score were selected. Then, the participants were divided into two groups, one the experimental $(\mathrm{N}=$ $20)$ and the other the control $(\mathrm{N}=20)$. All of the participants were males and their ages varied from 14 to 25 . Their first language was Turkish.

\section{The Instruments}

To select homogeneous participants for the current study a modified TOEFL test from (Barron TOEFL Preparation Book) was administered. This test contained 50 items. This test consisted of reading comprehension (20 items in forms of Multiple-choice items), grammar (27 items in the form of multiple choice), and writing (3tems including three topics for writing) for homogenizing their language proficiency. The allocated time for answering the questions was 1 hour. After correcting the papers, 40 students were selected as the advanced learners out of 58 students. The score for the proficiency test was out of 100.

The dictogloss was used as another instrument of data collection. The dictogloss is an activity where learners are introduced to a topic and are supposed to work through the reconstruction of a text on the same topic with a partner. A grammar test was used as both for the pretest and the posttest.

\section{Procedure}

To do this research, the researcher selected two classes at advance level to do the research. A proficiency test was administered to be sure of the homogeneity of the participants. A grammar test as a pretest was administered to measure students' grammar knowledge before the treatment. In the treatment, some selective tenses including all types of passives were taught during eight sessions in one month. In each of the 8 sessions, one special passive tense was instructed. This paper set out to compare the performance of EFL learners of advance proficiency on completing grammatical sentences either in the form of multiple choice or cloze test. Each task in the experimental group was completed collaboratively. It means that students in the experimental group after getting the grammar explanation by the teacher; they were supposed to complete the exercises collaboratively by the help of their peers or even the teacher. Students in the experimental group received a dictogloss activity. It is a text passage of approximately 250 words which contained the special instances of the L2 structure in this study. The focus was on passive tenses to be reconstructed in the experimental group. The texts were selected from Cambridge TOEFL book. The teacher read the passage at normal speed twice. The first time students just listened, the second time they made notes. Students had to share what they remembered and attempted to reconstruct the text in pairs or small groups. The instructor reminded the participants to pay attention to the usage of the L2 forms especially passive tenses in the text. The purpose of this metatalk task was working together with the partner in reconstructing a text. These learners were encouraged to notice linguistic problems and then engage in discussing language forms so that the structure could be made correct. They discussed the content and shared their ideas in order to reconstruct the text. The time allocated to the task performance was 25 minutes in each session. At the end of the dictogloss activity, teacher collected their papers and tried to review the papers and gave feedback about the correct use of the passive verb forms which was the intention of the language learning. In control group teacher as the researcher explained the selected grammatical items on the board. After the instruction, students had to answer the exercises individually at home or in the class. The next session they reviewed the answers in the class. 
Finally, the same grammar test in the pre-test was administered to both groups of the study in the posttest to find out the possible effect of metatalk activity as the independent variable on the learners' grammar knowledge as the dependent variable. This grammar test included 60 items. There were 30 items in the multiple choice form and 30 items in the fill in the blank form. The focus of the test was passive verbs. The grammar test was selected from a Cambridge TOEFL Preparation book for the pretest and the posttest. The scores of the posttest were compared with the pretest scores through independent t-test analysis.

\section{RESULTS}

The data in this study was obtained through calculating the descriptive statistics as well as the inferential statistical method of independent samples T-test for determining the effect of the independent variable on the dependent variable and the degree of progress of the participants from the pretest to the posttest. The results of t-test on TOEFL test for homogenizing two groups are shown in Table 1.

Table-1: Independent sample t-test for TOEFL scores

\begin{tabular}{|l|l|l|l|l|l|l|l|l|}
\hline group & $\mathbf{N}$ & mean & $\begin{array}{l}\text { Std. } \\
\text { Deviation }\end{array}$ & $\begin{array}{l}\text { Std. } \\
\text { Error } \\
\text { Mean }\end{array}$ & $\begin{array}{l}\text { Sig(2- } \\
\text { tailed) }\end{array}$ & F & t & df \\
\hline control & 20 & 64.75 & .01350 & .04235 & .810 & 1.583 & -.244 & $\begin{array}{l}38 \\
37.217\end{array}$ \\
\hline experimental & 20 & 65.61 & .07624 & .04377 & .810 & & -.244 & \\
\hline
\end{tabular}

As Table 1 shows, scores in the TOEFL test for the control group are $(\mathrm{M}=64.75, \mathrm{SD}=.013)$ and experimental group $(\mathrm{M}=65.61 \mathrm{SD}=.076), \mathrm{t}(38)=-.244, \mathrm{P}>.05$. The results show that there isn't a significant difference between two groups.

Table-2: Independent Sample t-test for the Grammar Test in the Pre and Post Tests

\begin{tabular}{|l|l|l|l|l|l|l|l|l|}
\hline group & $\mathbf{N}$ & mean & $\begin{array}{l}\text { Std. } \\
\text { Deviation }\end{array}$ & $\begin{array}{l}\text { Std. } \\
\text { Error } \\
\text { Mean }\end{array}$ & $\begin{array}{l}\text { Sig(2- } \\
\text { tailed) }\end{array}$ & $\mathbf{F}$ & $\mathbf{t}$ & df \\
\hline Pre control & 20 & 24.65 & .09150 & .02135 & .750 & 1.383 & -.194 & 38 \\
\hline experimental & 20 & 23.61 & .07624 & .04177 & .750 & & -.194 & \\
\hline Post control & 20 & 30.84 & .24583 & .01218 & .000 & 25.925 & -1.259 & $\begin{array}{l}38 \\
\end{array}$ \\
\hline experimental & 20 & 51.19 & .26576 & .03325 & .000 & & -1.259 & \\
\hline
\end{tabular}

As Table 2 shows, scores in the pre-test for the control group are $(\mathrm{M}=24.65, \mathrm{SD}=.091)$ and experimental group $(\mathrm{M}=23.61 \mathrm{SD}=.076), \mathrm{t}(38)=-.194, \mathrm{P}>.05$. The mean score shows that two groups grammar knowledge in the pre-test were the same. In the post-test, scores for the control group $(\mathrm{M}=30.84, \mathrm{SD}=.24)$ and the experimental group $(\mathrm{M}=51.19$, $\mathrm{SD}=.26), \mathrm{t}(38)=-1.259, \mathrm{P}=.000$. The results show that there is a significant difference between two groups in the posttest. In the post-test, the experimental group outperforms the control group in the grammar test.

\section{Discussion AND CONCluSion}

The present study aims to investigate the effect of metatalk activity on improving knowledge of passive verbs. The results revealed the effectiveness of the metatalk activity over the traditional method in teaching the grammar structures. The results showed that there was a significant difference between the students' performance before and after raising the L2 learners' awareness about English passive verb tenses. In other words, metatalk can be influential in acquiring passive tenses. It can be concluded that the metatalk activity could positively affect L2 learning when they had a specific linguistic focus. The results in the posttest scores revealed that in the experimental group participants improved their production of the L2 forms better than the control group. It might be because of the reception of immediate feedback from their peers on their linguistic choices.

The findings of the present study are in line with Watanabe and Swain's [8] claim that when involved in the collaborative dialog, the learners are more probably to get higher posttest scores. This study showed the superiority of the collaborative output task in doing language activities since it promotes noticing to meaning or form. Moreover, metatalk is expected to happen especially during the reconstruction period. Furthermore, Metatalk can raise awareness and promote noticing [9]. In addition, metatalk can have a positive effect on the development of learners' interlanguage. 
Collaboration which happens in metatalk process directs learners' attention towards certain linguistic features through reflection and discussion [5, 10]. As a whole, it seems that using metatalk can be helpful in grammar teaching. Teachers should include this approach in their curriculum designing. In addition, it is recommended to repeat this study for different gender and different levels of language proficiency.

\section{REFERENCES}

1. Swain, M. (2001). Integrating language and Content Teaching throughout Collaborative Tasks. Canadian Modern Language Review, 58(1), 44-63.

2. Vanderheijden, V. (2010). "Is That English I Hear Over There?" Rethinking the Prohibition on L1 Use in Foreign Language Learning. Texas Papers in Foreign Language Education (TPFLE), 14(1), 3-17.

3. Swain, M. (1985). Communicative competence: Some roles of comprehensible input and comprehensible output. In S. Gass \& C. Madden (Eds.), Input in second language acquisition. New York, NY: Newbury House, 235-256.

4. Krashen, S. (1982). Principles and Practice in Second Language Acquisition. Oxford: Pergamon Press.

5. Kowal, M., \& Swain, M. (1997). From semantic to syntactic processing: How can we promote metalinguistic awareness in the French immersion classroom? In R. Johnson (Ed.), Immersion education: International perspectives. Cambridge, UK: Cambridge University Press, 284-309.

6. Kuiken, F., \& Vedder, S.C. (2005). Noticing and the role of interaction in promoting language learning. In A. Housen \& M. Pierrard (Eds). Investigations in instructed second language acquisition. Berlin/New York: Mouton De Gruyter, 353-381.

7. Ellis, R. (2000). Task-based research and language pedagogy. Language Teaching Research, 4(3), 193-220.

8. Watanabe, Y., \& Swain, M. (2007). Effects of proficiency differences and patterns of pair interaction on second language learning: collaborative dialogue between adult ESL. Language Teaching Research, 11, 121-142

9. Swain, M. (1998). Focus on form through conscious reflection. In Focus on Form in Classroom L2 Acquisition, C. Doughty \& J. Williams (Eds.). New York: Cambridge, 64-82.

10. Myhill, D. A. (2000). Misconceptions and difficulties in the acquisition of Meta linguistic knowledge. Language and Education, 14(3) 151-163. 